\title{
PARTIAL ASSESSMENT OF THE DEGREE OF MAN AND THE WORLD OF WORK TEACHING IMPLEMENTATION AT BASIC SCHOOLS BASED ON ANALYSIS OF SCHOOL EDUCATIONAL PROGRAMMES OF SELECTED SCHOOLS
}

\author{
Martin HAVELKA
}

\begin{abstract}
In the last few years teaching in accordance with new curricular documents reflecting the school educational programmes of individual schools was gradually implemented on the level of basic education. This paper aims at assessing of the degree of general technical subject (Man and the world of work) teaching implementation at basic schools after implementing the mentioned changes based on analysis of selected school educational programmes.
\end{abstract}

Key words: Framework educational programme for basic education, school educational programme, assessment of the degree of teaching general technical subject, man and the world of work.

\section{DÍLČÍ POSOUZENÍ STAVU REALIZACE VÝUKY VZDĚLÁVACÍ OBLASTI ČLOVĚK A SVĚT PRÁCE NA ZÁKLADNÍCH ŠKOLÁCH NA ZÁKLADĚ ANALÝZY ŠKOLNÍCH VZDĚLÁVACÍCH PROGRAMŮ VYBRANÝCH ŠKOL}

Resumé: V uplynulých letech byla na úrovni základního školství postupně realizována výuka v souladu s novými kutikulárními dokumenty, které se promitaji do školních vzdělávacích programi jednotlivých základních škol. Přispěvek se snaži o posouzení stavu realizace výuky obecně technického předmětu (vzdělávaci oblasti Člověk a svět práce) na základních školách po realizaci uvedených změn na základě analýzy vybraných školních vzdělávacích programů.

Kličcová slova: Rámcový vzdělávaci program pro základni vzdělávání, školni vzdělávací program, posouzení stavu výuky obecně technického předmětu, vzdělávaci oblast Člověk a svět práce.

\section{1 Úvod}

Předchozí koncepce kurikula charakteristická mj. velmi podrobně formulovanými osnovami byla reprezentována hlavně Vzdělávacím programem Základní škola (1). Od září roku 2005 byla postupně nahrazena odlišnou koncepcí, v níž příslušný RVP (zde Rámcový vzdělávací program pro základní vzdělávání, dále jen RVP ZV, (2)) definuje pouze rámec - vymezuje vzdělávací oblasti, průřezová témata a stanoví jen velmi obecné cílové struktury v podobě klíčových kompetencí. Konkrétní osnovy si $\mathrm{v}$ takto definovaném rámci sestavují jednotlivé základní školy (dále jen ZŠ) v podobě Školního vzdělávacího programu (dále jen ŠVP).

Kladem této koncepce je bezesporu možnost profilace školy ve smyslu přizpůsobení vzdělávací nabídky jejím personálním a materiálním možnostem a požadavkům žáků.

V předcházejícím Vzdělávacím programu Základni škola byly v rámci výuky obecně technického předmětu realizovány jako povinné všechny zde vymezené tematické celky: (1. stupeň: Práce s drobným materiálem, Práce smodelovaci hmotou, Práce spapírem a kartonem, Práce s textilem, Práce montážni a demontážní, Lidové zvyky, tradice a řmesla, Pěstitelské práce, U nás doma, 2. stupeň: Práce s počitačem, Pěstitelství, Práce s technickými materiály, Elektrotechnika kolem nás, Provoz a údržba domácnosti, Př́iprava pokrmů, Svět práce).

Z hlediska výuky obecně technického předmětu na ZŠ (dále jen OTP) v rámci realizace nového konceptu RVP ZV/ŠVP jsou důležité vzdělávací oblasti Člověk a svět práce a Informační a komunikační technologie. Oba obsahují vzdělávací obory stejného jména. Obdobná analýza stavu výuky vzdělávacího oboru Informační a komunikační technologie je uvedena ve stati (3). Nyní se zaměříme na vzdělávací obor Člověk a svět práce, který je rozdělen na 1. stupni na čtyři tematické okruhy: Práce $s$ drobným materiálem, Konstrukční činnosti, Pěstitelské práce, Př́prava pokrmů, které jsou pro školu povinné. Na 2. stupni je rozdělen na osm tematických okruhů Práce s technickými materiály, Design a konstruování, 
Pěstitelské práce a chovatelství, Provoz a údržba domácnosti, Př́prava pokrmů, Práce slaboratorní technikou, Využití digitálních technologií, Svět práce. Tematické okruhy na 2. stupni tvoří nabídku, z níž tematický okruh Svět práce je povinný, a z ostatních školy vybírají podle svých podmínek a pedagogických záměrů minimálně jeden další okruh. Vybrané tematické okruhy je nutné realizovat v plném rozsahu. (2, s. 73)

Jako riziko nového pojetí lze označit stav, kdy ZŠ do svého ŠVP musí jako povinný zařadit tematický okruh Svět práce a z ostatních (viz výše) vybírají podle svých podmínek minimálně jeden další okruh. (2, s. 73) K posílení výuky témat, které škola v ŠVP akcentuje jsou využívány disponibilní hodiny v kombinaci s povinně volitelnými a volitelnými vyučovacími předměty.

V následující části bude provedena analýza dostupných dat, která lze abstrahovat ze školami zveřejněných ŠVP s ohledem na možnosti posouzení stavu výuky OTP na vybraných ZŠ. Vzhledem ke skutečnosti, že ne všechny ZŠ svůj ŠVP zveřejňují na svých www stránkách, bylo upuštěno od metodologicky vhodnějšího výběru posuzovaných ŠVP ze všech dostupných a kdalšímu posouzení byly použity všechny dostupné ŠVP až do té míry, dokud nebyl získán dostatečný počet vstupních dat. Takto získaný vzorek tedy není reprezentativní, a má omezenou vypovídací schopnost. Celkem bylo porovnáno 23 ŠVP ZŠ, jejich seznam je dostupný u autora př́spěvku. Pokud posuzovaný ŠVP obsahoval pro danou oblast více variant (napřs. sportovní a informatická tř́da, či rozdělení na chlapce a dívky), posuzují se tyto varianty jako samostatné ŚVP.

\section{Výuka vzdělávací oblasti Člověk a svět práce}

Nyní se zaměřme na realizaci výuky vzdělávací oblasti Člověk a svět práce na vybraných ZŠ. V RVP ZV (2) jsou minimální počty hodin pro první stupeň (1. a 2. etapa vzdělávání) 5 vyučovacích hodin týdně a pro druhý stupeň (3. etapa) potom 3 vyučovací hodiny týdně.

Vezmeme-li $\mathrm{v}$ úvahu jen rozsah povinné výuky, je v průměru na 1 . stupni sledovaných škol výuka vzdělávací oblasti Člověk a svět práce (tematické okruhy: Práce $s$ drobným materiálem, Konstrukční činnosti, Pěstitelské práce, Príprava pokrmů) realizována s týdenní dotací výuky $(5,0 \pm 0,2)$ vyučovací hodiny, přičemž minimální týdenní hodinová dotace stanovená v RVP ZV je v první a druhé etapě (1. stupeň) 5 vyučovacích hodin týdně.

Pokud však přihlédneme také $\mathrm{k}$ povinně volitelným a volitelným hodinám, je na 1. stupni sledovaných škol výuka vzdělávací oblasti Člověk a svět práce realizována s týdenní dotací výuky $(5,17 \pm 0,62)$ vyučovací hodiny; minimální týdenní hodinová dotace stanovená v RVP ZV je zde již uvedených 5 vyučovacích hodin týdně.

Zde můžeme uvést, že jedna ze sledovaných 23 škol předepsanou dotaci 5 vyučovacích hodin použila k posílení Výtvarné výchovy a Prvouky, v nichž na 1. stupni předepsané kompetence z oblasti Člověk a svět práce realizuje, jedna ze škol posílila výuku oblasti Člověk a svět práce na 1. stupni jednou disponibilní hodinou týdně a jedna ze škol zavedla na 1. stupni volitelný prredmět Technické praktikum s týdenní dotací 3 vyučovací hodiny.

$\mathrm{Na}$ druhém stupni je ve sledovaných ZŠ situace následující:

Vezmeme-li v úvahu jen rozsah povinné výuky, je v průměru na 2 . stupni sledovaných škol výuka vzdělávací oblasti Člověk a svět práce realizována $\mathrm{s}$ týdenní dotací výuky $(3,96 \pm 1,35)$ vyučovací hodiny, přičemž minimální týdenní hodinová dotace stanovená v RVP ZV je ve třetí etapě (2. stupeň) 3 vyučovací hodiny týdně.

Zde je třeba uvést, že ZŠ, která dle Grafu 1 realizuje výuku vzdělávací oblasti Člověk a svět práce s týdenní dotací 1 hodina realizuje další 4 hodiny jako volitelné (ve dvou dvouhodinových blocích), je tak dodržena minimální předepsaná týdenní dotace. 


\section{Graf 1: Týdenní hodinová dotace výuky Praktických činností na 2. stupni v posuzovaných ZŠ}

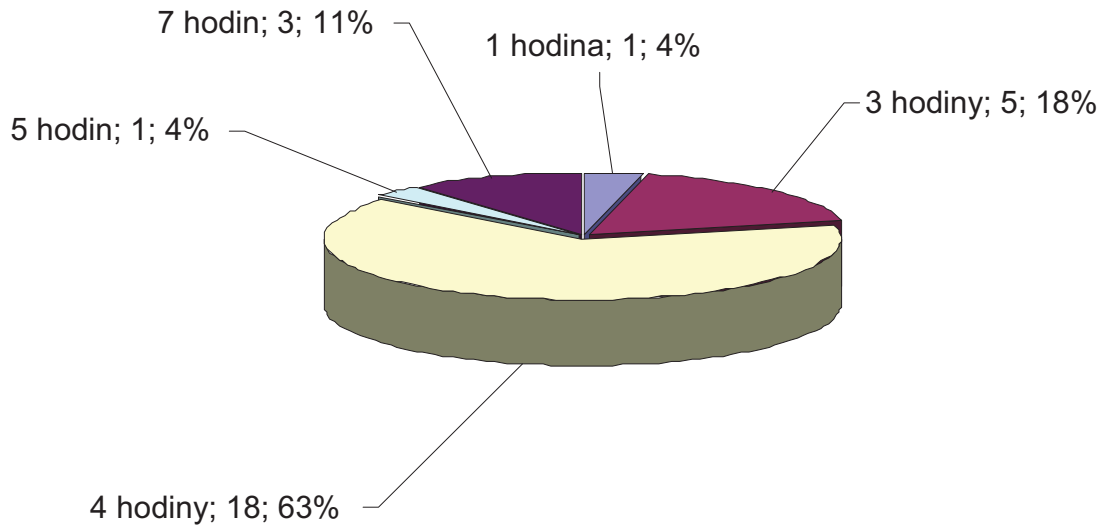

Graf 1: Týdenní hodinová dotace výuky Praktických činností na 2. stupni v posuzovaných ZŠ

Pokud přihlédneme i $\mathrm{k}$ vyučovacím hodinám realizovaným $\quad \mathrm{v}$ rámci povinně volitelné a volitelné výuky, je na 2 . stupni sledovaných škol výuka vzdělávací oblasti Člověk a svět práce realizována s týdenní dotací výuky $(5,95 \pm 2,81)$ vyučovací hodiny (opět při minimální týdenní hodinové dotaci 3 vyučovací hodiny), viz Graf 2.

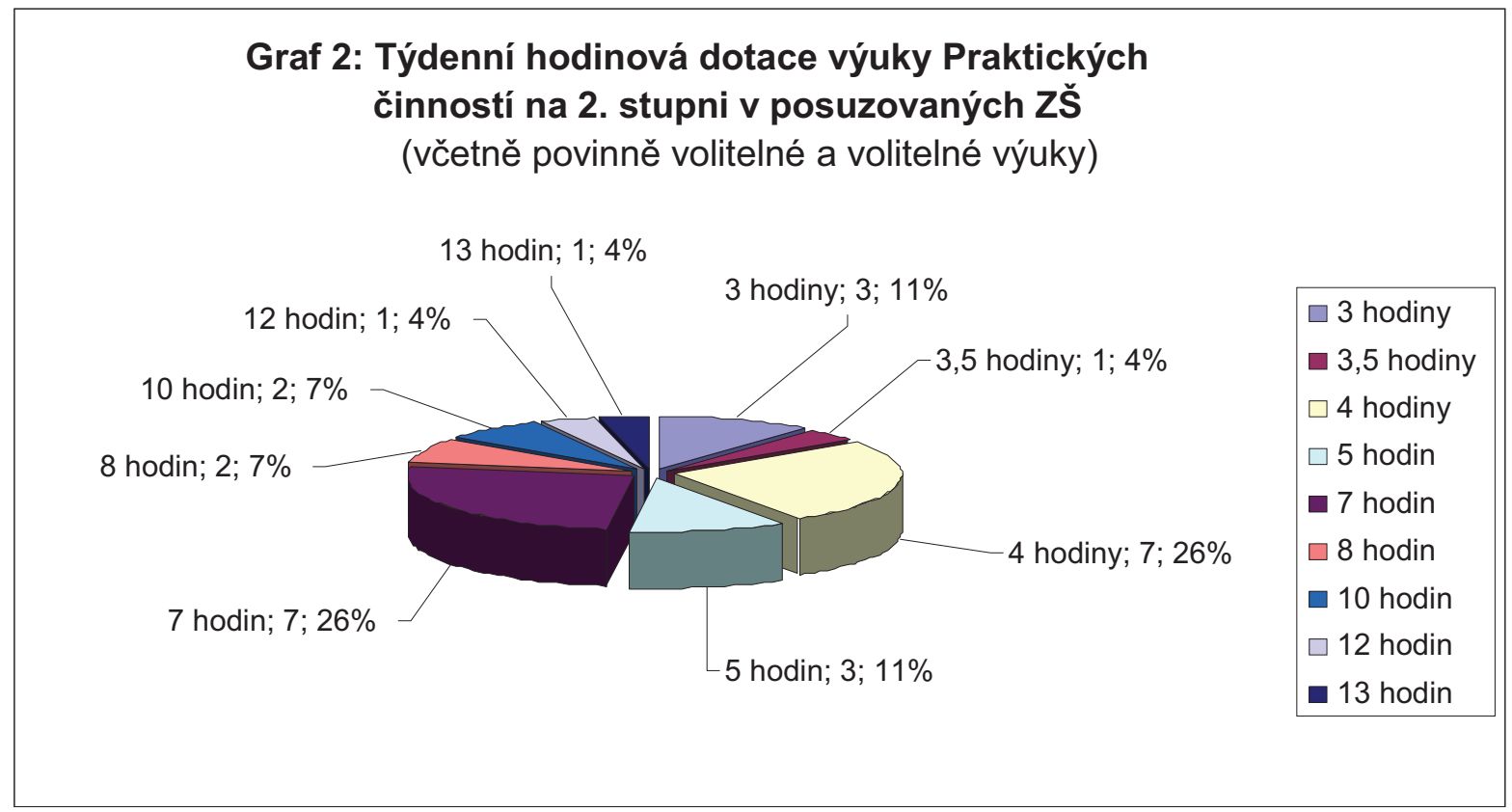

Graf 2: Týdenní hodinová dotace výuky Praktických činností na 2. stupni v posuzovaných ZŠ (včetně povinně volitelné a volitelné výuky)

Nyní se blíže zaměříme na realizaci výuky vzdělávací oblasti Člověk a svět práce z hlediska zastoupení jednotlivých tematických okruhů. Graf 3 zobrazuje průměrné percentuální zastoupení jednotlivých tematických okruhů v realizované výuce. 


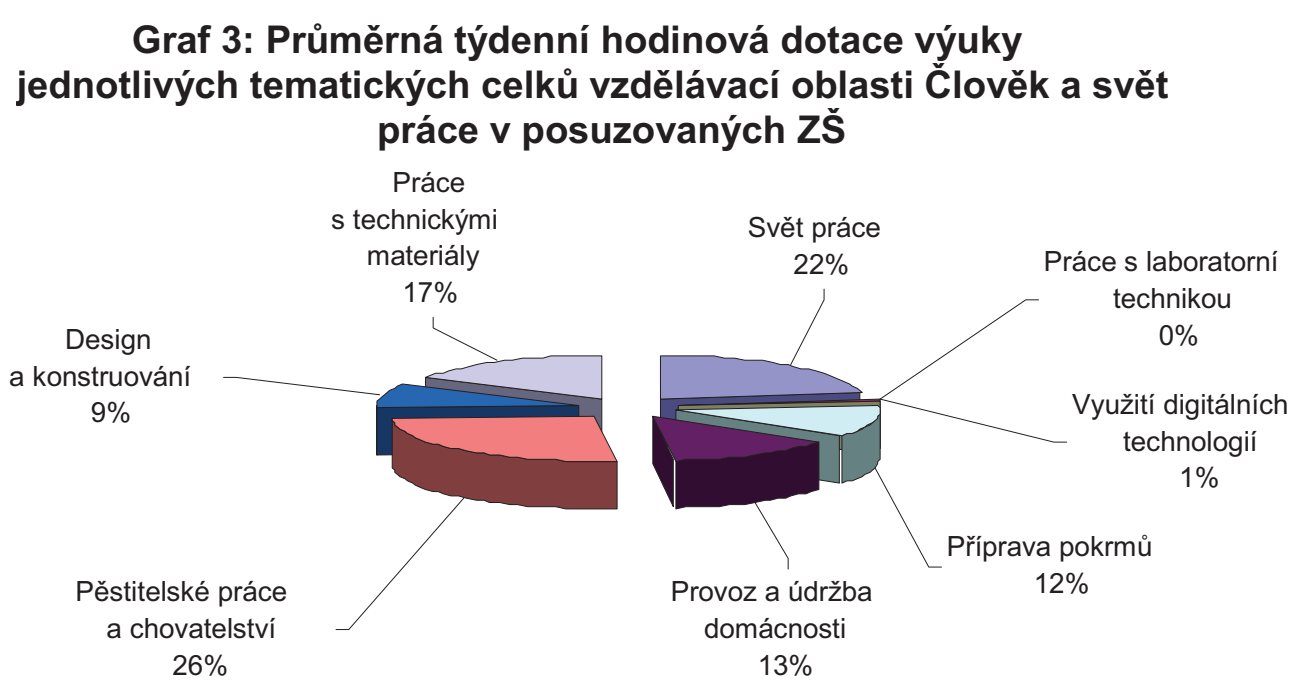

Graf 3: Průmèrná týdenní hodinová dotace výuky jednotlivých tematických celků vzdèlávací oblasti Člověk a svět práce v posuzovaných ZŠ

V následující tabulce jsou data směrodatné odchylky. Extrémy jsou vyznačeny z předcházejícího grafu doplněna o hodnotu barevně.

\begin{tabular}{|c|c|c|c|c|c|c|c|c|}
\hline tematický okruh & 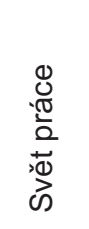 & 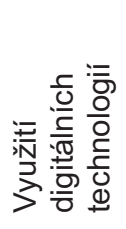 & 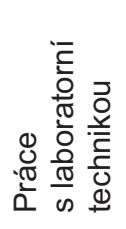 & 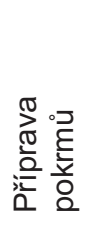 & 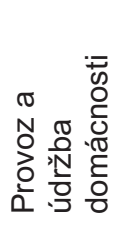 & 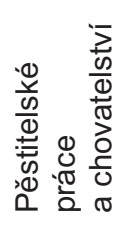 & 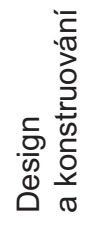 & 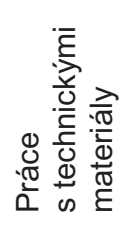 \\
\hline $\begin{array}{l}\text { průměrná týdenní } \\
\text { hodinová dotace }\end{array}$ & 0,92 & 0,04 & 0 & 0,50 & 0,55 & 1,1 & 0,4 & 0,70 \\
\hline směrodatná odchylka & 0,62 & 0,13 & 0 & 0,59 & 0,58 & 1,3 & 0,5 & 0,84 \\
\hline
\end{tabular}

Tabulka 1: Průměrná týdenní hodinová dotace výuky tematických okruhů vzdělávací oblasti Člověk a svět práce /pouze povinná výuka/

Extrémy zachycené v Tabulce 1 lze interpretovat následovně:

- Vysoké hodnoty průměrné týdenní hodinové dotace vykazují položky „Svět práce“ a „Pěstitelské práce a chovatelství“, což značí, že výuce uvedených tematických okruhů je na školách věnováno více času.

- Nízké hodnoty průměrné týdenní hodinové dotace vykazují položky „Využití digitálních technologii“" a „Práce s laboratorní technikou“ což značí, že výuce uvedených tematických okruhů je na školách věnováno velmi málo času a tematický okruh „Práce s laboratorní technikou“ není na sledovaných školách realizován vůbec.

- Vysoké hodnoty směrodatné odchylky vykazují položky „Pěstitelské práce a chovatelstvi“ a „Práce s technickými materiály", to značí, že výuce uvedených tematických okruhů je na některých školách věnováno hodně času a na některých naopak málo, nebo zde př́padně nejsou vyučovány vůbec.

- Nízké hodnoty směrodatné odchylky vykazují položky „Využití digitálních technologii““ a „Práce s laboratorní technikou“, to značí, že výuka uvedených tematických okruhů je na všech školách na téměř shodné úrovni.

Nyní se zaměříme na realizaci výuky vzdělávací oblasti Člověk a svět práce z hlediska zastoupení jednotlivých tematických okruhů $\mathrm{s}$ tím, že vezmeme v úvahu i podíl disponibilních hodin, které školy pro tuto výuku vyčlenily. 
Graf 4 zobrazuje průměrné percentuální v realizované výuce. zastoupení jednotlivých tematických okruhů

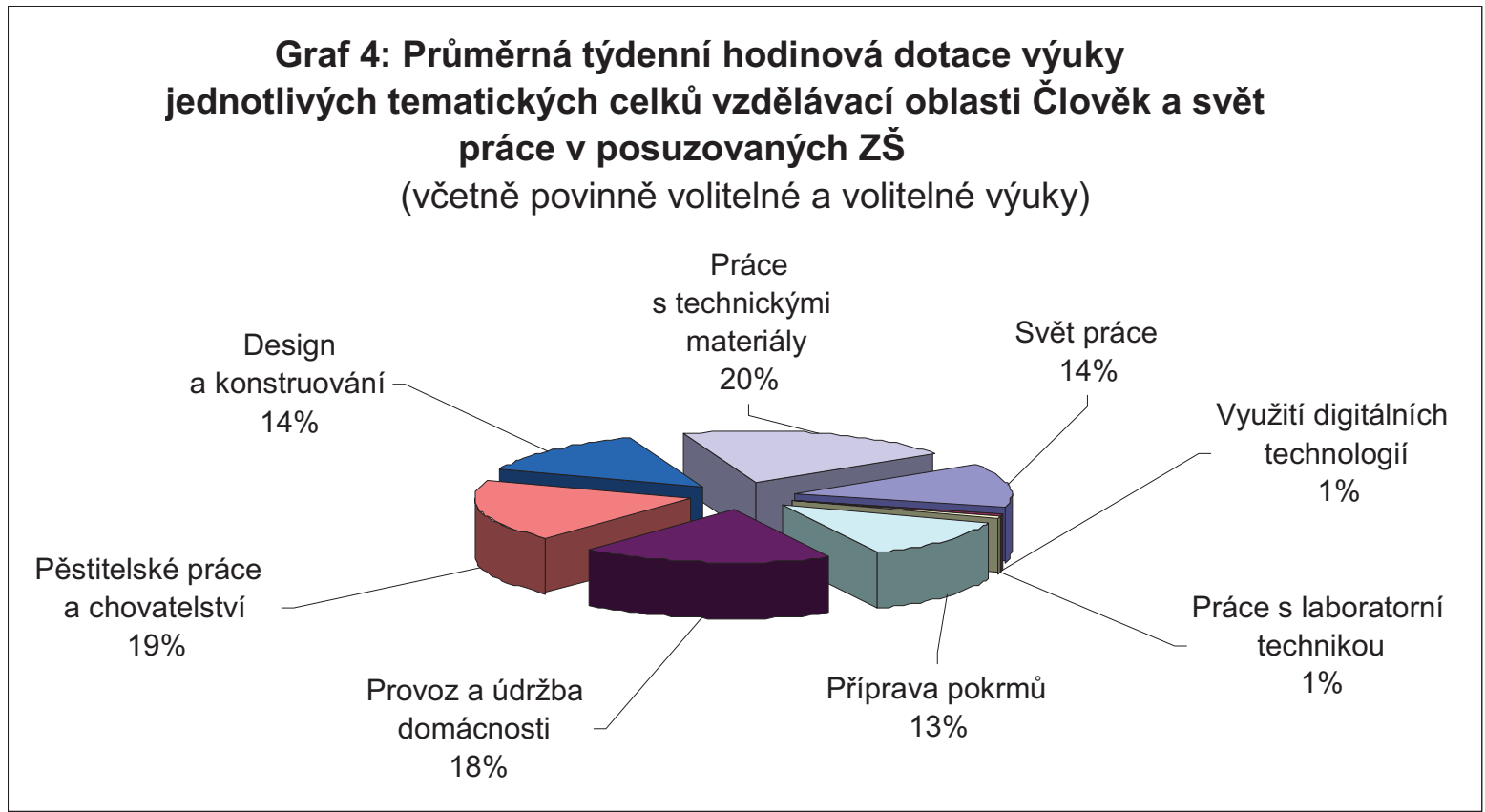

Graf 4: Prưměrná týdenni hodinová dotace výuky jednotlivých tematických celků vzdělávací oblasti Člověk a svět práce v posuzovaných ZŠ (včetně povinně volitelné a volitelné výuky)

Data z předcházejícího grafu doplněná v následující tabulce. Extrémy jsou vyznačeny o hodnotu směrodatné odchylky se nacházejí barevně.

\begin{tabular}{|c|c|c|c|c|c|c|c|c|}
\hline tematický okruh & 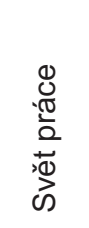 & 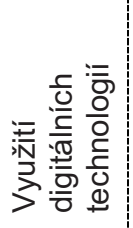 & 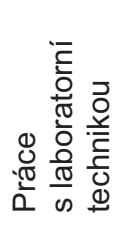 & 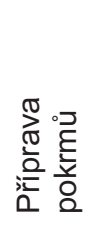 & 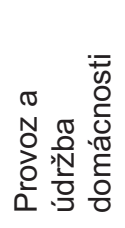 & 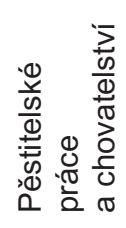 & 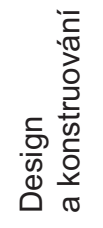 & 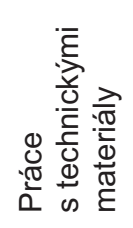 \\
\hline $\begin{array}{l}\text { průměrná týdenní } \\
\text { hodinová dotace }\end{array}$ & 0,81 & 0,04 & 0,03 & 0,75 & 1,13 & 1,13 & 0,82 & 1,24 \\
\hline směrodatná odchylka & 0,54 & 0,13 & 0,13 & 1,12 & 1,40 & 1,24 & 1,14 & 1,12 \\
\hline
\end{tabular}

Tabulka 2: Prưměrná týdenní hodinová dotace výuky tematických okruhů vzdělávací oblasti Člověk a svět práce /včetně povinné a povinně volitelné výuky/

Extrémy zachycené v Tabulce 2 lze interpretovat shodně jako $\mathrm{v}$ předcházejícím př́ípadě. Je vhodné si všimnout, že $\mathrm{v}$ př́ípadě, kdy byly vzaty $\mathrm{v}$ úvahu týdenní hodinové dotace výuky tematických okruhů vzdělávací oblasti Člověk a svět práce včetně povinné a povinně volitelné výuky, situace minimálně realizovaných či vůbec nerealizovaných tematických okruhů „Využití digitálních technologií“ a „Práce s laboratorní technikou“" se výrazně nezměnila. V př́ípadě „opačné části pořadí" však ke změnám dochází. Názorně to ukazuje srovnání Grafu 5 a Grafu 6: 


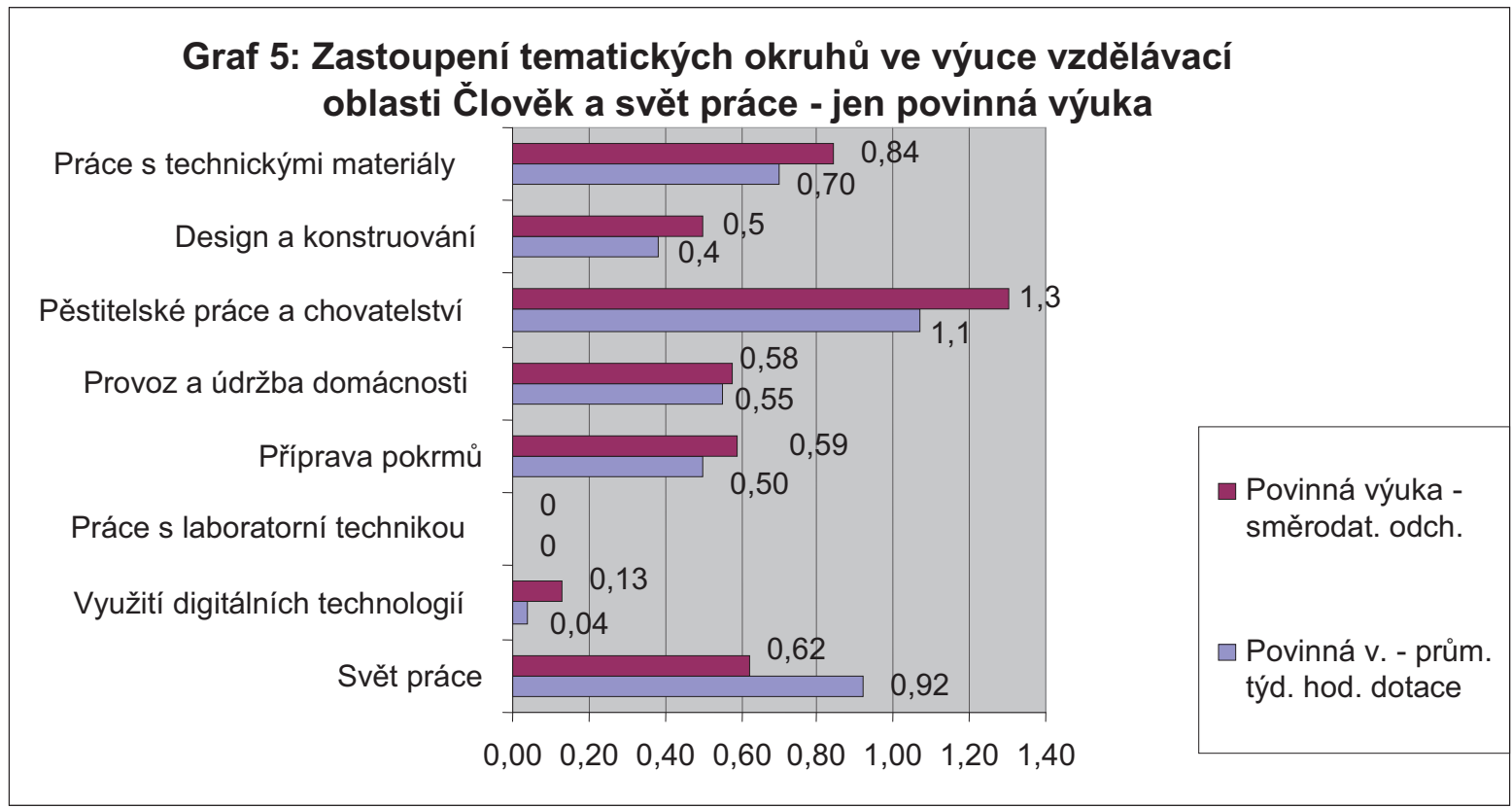

Graf 5: Zastoupení tematických okruhů ve výuce vzdělávaci oblasti Člověk a svět práce (zahrnuta jen povinná výuka)

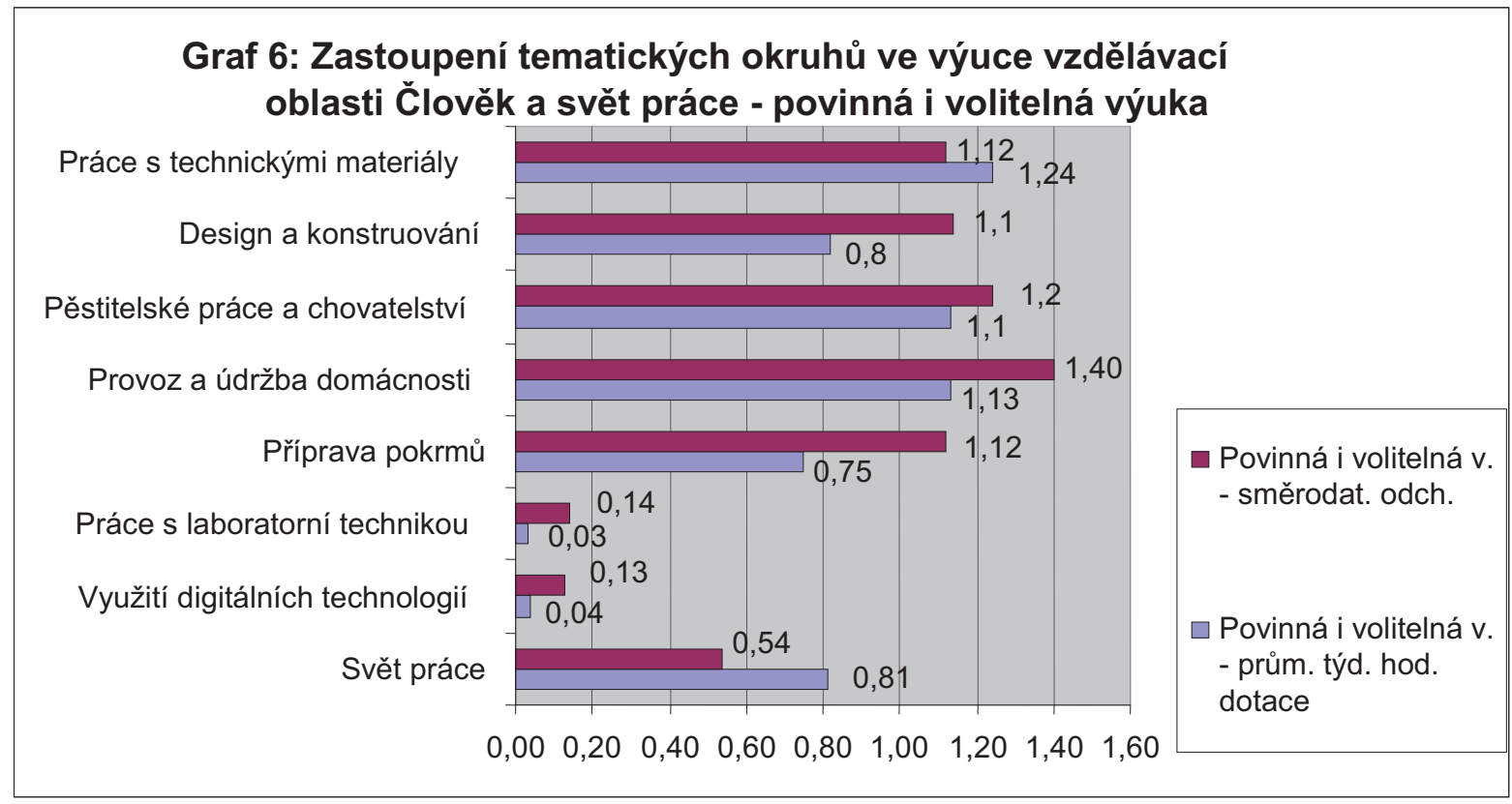

Graf 6: Zastoupení tematických okruhů ve výuce vzdělávací oblasti Člověk a svět práce (zahrnuta povinná i volitelná výuka)

\section{Závěr}

Vzhledem k charakteru zdroje dat použitých pro provedenou analýzu (z jednotlivých ŠVP ve většině př́ípadů nelze vyčíst konkrétní hodinové dotace u jednotlivých tematických okruhů) a vzhledem k omezenému počtu 23 analyzovaných ŠVP nelze získané výsledky generalizovat, svou vypovídací hodnotu však mají alespoň pro uvedené ZŠ.
Má-li být jedním z př́nosů realizace RVP ZV v praxi vytvoření prostoru pro profilaci jednotlivých ZŠ a rozrůznění vzdělávací nabídky poskytované žákům, pak lze na základě vysoké míry směrodatné odchylky od průměrné hodnoty týdenní hodinové dotace věnované jednotlivým tematickým okruhům usuzovat, že v oblasti výuky obecně technického předmětu (resp. 
vzdělávací oblasti Člověk a svět práce) tuto funkci na sledovaných školách plní.

Je pozitivním zjištěním, že zvláště na druhém stupni ZŠ je výuka vzdělávací oblasti Člověk a svět práce realizována i sužitím části disponibilních hodin, tj. nad rámec stanovené minimální hodinové dotace 3 hodiny týdně; průměrně je to $(5,95 \pm 2,81)$. Dále je pozitivní, že v $52 \%$ posuzovaných ŠVP jsou v nabídce volitelných či povinně volitelných předmětů také ty, jejichž obsahem je náplň tematických okruhů vzdělávací oblasti Člověk a svět práce.

Jako problematický vnímáme v RVP definovaný výčet tematických okruhů, které jsou ve výuce vzdělávací oblasti Člověk a svět práce realizovány. Srovnáním VP ZŠ (1) a RVP ZV (2) $\mathrm{v}$ oblasti OTP přicházíme $\mathrm{k}$ závěru, že zde mj. chybí důležitý tematický okruh Elektrotechnika kolem nás. Ćástečně se jeho obsah může uplatnit v tematických okruzích Design a konstruováni a Práce s laboratorni technikou, ale je to dle našeho názoru „nouzové“ řešení, nebot' právě Práce slaboratorní technikou je realizována v zanedbatelní míre. Obsah spadající do tematického okruhu Elektrotechnika kolem nás se v určité (většinou však zanedbatelné míře) objevil jen ve čtyřech ŠVP z celkem 23 posuzovaných! Blíže se o této problematice zmiňuje autor O. Janda v práci (3).

Stejně tak se i problematika práce s konstrukčními stavebnicemi (tolik charakteristická pro OTP) ve sledovaných ŠVP explicitně na druhém stupni vyskytuje jen ve dvou př́padech. Jako dílčí řešení se $v$ této souvislosti mj. voblasti pregraduální př́pravy učitelů v oblasti oborové didaktiky OTP jeví širši uplatnění problematiky konstrukčních a elektrotechnických stavebnic a jejich aplikace ve výuce nejen na ZŠ. Jen dobře připravený učitel znalý práce s různými druhy konstrukčních a elektrotechnických stavebnic je v praxi skutečně zařadí do ŠVP. A jen nadšený a zapálený učitel ke svému oboru přitáhne žáky a dokáže vzbudit jejich zájem.

Otázkou dále zůstává, zda uvedená strukturace vzdělávací oblasti Člověk a svět práce a aktuální pojetí výuky této problematiky je vhodné vzhledem k aktuálním potřebám zvýšení zájmu žáků všech typů škol o technické a př́rodovědné obory.

\section{Literatura}

[1] kol. Vzdělávací program Základní škola 2., dopl. vyd. Praha : Fortuna, 2001. 344 s. ISBN 807168-595-X.

[2] kol. Rámcový vzdělávací program pro základní vzdělávání. Praha : VÚP, 2007. $126 \mathrm{~s}$. [cit 2010-04-27] [on-line] Dostupné z URL: $<$ http://www.vuppraha.cz/wpcontent/uploads/2009/12/RVPZV_2007071.pdf $>$.

[3] HAVELKA, M. Dílčí posouzení stavu realizace výuky vzdělávací oblasti Informační a komunikační technologie na základních školách na základě analýzy školních vzdělávacích programů vybraných škol. In Trendy ve vzdělávání 2010. Olomouc : ALTYN, 2010. s. 78 - 82. ISBN 978-80-87224-09-0.

[4] JANDA, O. Absence techniky a technické výchovy $\mathrm{v}$ učebních plánech pro základní vzdělávání. In Trendy ve vzděláváni 2009. Olomouc : VOTOBIA Olomouc, 2009. s. 77 83. ISBN 978-80-7220-316-1.

Př́íspěvek vznikl v rámci řešení projektu FRVŠ č. $1531 / 2010$.

Mgr. Martin Havelka, Ph.D.

Katedra technické a informační výchovy

Pedagogická fakulta UP

Žižkovo nám. č. 5

771 40, Olomouc, ČR

Tel: +420 585635812

E-mail: havelkam@pdfnw.upol.cz

Www pracoviště: www.kteiv.upol.cz 